\title{
Samhandlingsreformen og universitetene
}

I Stortingsmelding nr. 47 (Samhandlingsreformen - Rett behandling - på rett sted - til rett tid) presenteres god samhandling som en strategi for bedre helsetjeneste til pasientene. Dessuten skal det være samfunnsøkonomisk gunstig (1). Stortingsmeldingen er rund og lite konkret, men det er tydelig hva som er målene. Siden prosessen rundt dokumentet har vært relativt lukket, kan det være like bra at virkemidler og tiltak ikke er endelig fastlagt. Både fagmiljøene og offentligheten trenger tid til å diskutere og konkretisere innholdet $\mathrm{i}$ reformen for at den skal få den nødvendige tillit og forankring.

Reformforslaget innebærer store endringer av helsetjenesten, og det stilles nye krav til helsearbeiderne. Stortingsmeldingen understreker at helsepersonell vil trenge ny kompetanse. Men hvem har ansvaret for at slik kompetanse utvikles hos de helsearbeiderne som vi utdanner? Og hva slags kunnskap skal denne kompetansen bygge på? Stortingsmeldingen formelig roper etter innsats fra undervisnings- og forskningsinstitusjonene, selv om disse institusjonene delvis ligger under et annet departement - Kunnskapsdepartementet. Vi som jobber med forskning og undervisning må bruke tiden godt fremover, dersom mer og ny kompetanse og forskning skal understøtte innføringen av reformen og følge effektene av den. Det er derfor gledelig at Kunnskapsdepartementet er involvert for å sikre at forsknings- og utdanningsinstitusjonene tilpasser seg nye oppgaver og behov for endret kompetanse hos studentene. Dette må gjelde fra grunnutdanningen til forskningsfronten.

Et utslag av reformen er at undervisningen av helsepersonell i langt større grad enn nå må få kommunehelsetjenesten som sitt siktemål. Det gjelder ikke minst medisinstudiet, som per i dag nærmest er et rent sykehusbasert studium, der studentene i altfor liten grad eksponeres for arbeid i kommunene. Vi må sikre at alle studentene kjenner den allmennmedisinske arenaen godt når de skal velge retning, slik at de som skal arbeide der vet hva de går til, og at de andre kjenner rammene godt nok til å bli gode samhandlere. Undervisning basert på sykdomsforløp kan bli et viktig tiltak i samhandlingens tid. De medisinske fakultetene må gjøre de nødvendige grep for å møte nye krav til moderne leger.

Undervisningen i medisinstudiet skal være forskningsbasert, og forskningen må også innrettes slik at den kan svare på de nye kompetansekravene. Primærmedisin blir enda viktigere med samhandlingsreformen, men hvordan skal vi styrke fastlegenes og samhandlingens kunnskapsbase? Vi trenger forskning på fastlegenes nye arbeidsoppgaver, kvaliteten på utførelsen og effekten på pasientene. Videreutvikling av fastlegenes vurderingskompetanse kan trenge et forskningsprogram alene. Et sentralt tema er å styrke allmennmedisinsk epidemiologisk kompetanse, som trengs ved vurderinger av sykehusinnleggelse på legevakt. Vidtrekkende kunnskap om forholdet mellom normalitet og sykdom er også et felt hvor ny kunnskap er nødvendig - når er atferden til en ungdom så avvikende at schizofreni bør mistenkes? Forskning som dokumenterer begrenset nytteverdi av «etablert» diagnostikk og behandling, og som kan gi fastlegene støtte til å avstå fra unødvendige tiltak vil også være av stor verdi fremover.

Norges forskningsråd er i forkant og vil allerede i høst arrangere en konferanse om utvikling av allmennmedisinsk forskning. Vil forsk- ningsinstitusjonene følge opp? Rekruttering av forskere blir et sentralt tema. Bare $2 \%$ av allmennlegene har doktorgrad, mens det tilsvarende tallet for alle andre leger samlet er $8 \%$. Forskning, fagutvikling, veiledning og undervisning er oppgaver vi trenger de nye fastlegene til, slik stortingsmeldingen også beskriver. Det er derfor forstemmende at meldingen har utelatt forskning og akademisk arbeid på listen over aktiviteter som kan inngå i fastlegenes faste, offentlige oppgaver.

På mange områder dreier samhandlingsreformen seg om å gjøre mer eller mindre av noe vi kan fra før. Imidlertid er det forskningsbaserte kunnskapsgrunnlaget svakt for mange av de nye tiltakene som er foreslått, spesielt gjelder dette forebygging av sykdom. Forebygging står sentralt i meldingen, og skal gjennom et løft få reell innvirkning på behovet for fremtidige sykehustjenester. Planer og aktiviteter for lokal helsetjeneste skal bygge på analyser av den lokale folkehelsen, ikke bare være basert på lokale sykdoms- og risikoprofiler samt pasientdata, men gjennom en samfunnsanalyse med mange sektorer involvert. Flere pasienter skal behandles i sitt nærmiljø, med høy medisinsk og pleiefaglig kvalitet på tjenestene, dog utenfor tradisjonelle sykehusrammer. Fastlegene skal kunne legge pasienter med behov for mer intensiv medisinsk behandling og pleie inn i kommunale institusjoner når innleggelse i sykehus ikke er nødvendig. Ferdigbehandlede skal raskest mulig ut av sykehuset og få et godt tilbud hjemme ved hjelp av fastlege og hjemmetjenester, eller de skal tilbys et mellomopphold for pleie og behandling i kommunal institusjon. Vi må imidlertid vite at tiltakene virker. Det må stilles krav til dokumentasjon og evaluering av samhandlingsprosedyrer, forebyggingsintervensjoner, nye yrkesgrupper og nye oppgaver hos de eksisterende, bruk av forsterkede sykehjem osv. Selv om noen tiltak kan innføres uten at det trengs forskningsmessig evaluering, er de fleste nye helsetjenestetiltakene lite egnet for politiske forhandlinger, og innføring kan ikke bare være basert på god vilje og fromme ønsker.

Nye roller og nye krav fordrer nye, kunnskapsbaserte svar, også på utdanningsfronten. Det tar mange år før effektene av endret utdanning og nytt kunnskapsgrunnlag vises i helsetjenesten. Universitetene og høgskolene har derfor ingen tid å tape om de i samhandlingsreformens ånd ønsker å være i pakt med fremtidens krav til kompetanse. Utdanningsinstitusjonene må gjøre jobben, både med undervisning og med kunnskapsgrunnlaget. Vil departementet påta seg den nødvendige pådriverrollen?

\section{Guri Rørtveit \\ guri.rortveit@isf.uib.no \\ Steinar Hunskår \\ steinar.hunskar@isf.uib.no}

Guri Rørtveit (f. 1965) er forskningsleder ved Allmennmedisinsk forskningsenhet i Bergen, Unifob helse, og professor ved Institutt for samfunnsmedisinske fag, Universitetet i Bergen. Hun er også leder av Tidsskriftets redaksjonskomité.

Steinar Hunskår (f. 1956) er professor ved Institutt for samfunnsmedisinske fag, Universitetet i Bergen, og forskningsleder ved Nasjonalt kompetansesenter for legevaktmedisin, Unifob helse.

\section{Oppgitte interessekonflikter: Ingen}

\section{Litteratur}

1. St.meld. nr. 47 (2008-2009). Samhandlingsreformen. Rett behandling - på rett sted - til rett tid. 